OPEN ACCESS

Approved by:

Frontiers in Psychiatry,

Frontiers Media SA, Switzerland

*Correspondence:

Frontiers Editorial Office

editorial.office@frontiersin.org

Specialty section:

This article was submitted to

Addictive Disorders,

a section of the journal

Frontiers in Psychiatry

Received: 13 December 2018 Accepted: 17 December 2018 Published: 22 January 2019

Citation:

Frontiers Editorial Office (2019)

Corrigendum: Outcome Evaluation of a Short-Term Hospitalization and

Community Support Program for

People Who Abuse Ketamine.

Front. Psychiatry 9:746.

doi: 10.3389/fpsyt.2018.00746

\section{Corrigendum: Outcome Evaluation of a Short-Term Hospitalization and Community Support Program for People Who Abuse Ketamine}

\author{
Frontiers Editorial Office* \\ Frontiers Media SA, Lausanne, Switzerland
}

Keywords: ketamine, drug misuse, outcome, evaluation, intervention, hospitalization, Chinese

\section{A Corrigendum on}

Outcome Evaluation of a Short-Term Hospitalization and Community Support Program for People Who Abuse Ketamine

by Siu, A. M. H., Ko, F. S. L., and Mak, S. K. (2018). Front. Psychiatry 9:313. doi: $10.3389 /$ fpsyt.2018.00313

In the original article, there was an error as one of the reviewers did not endorse the final version of the article. This correction is made to remove this individual as an endorsing reviewer on the article. The final, published article has been endorsed by the Specialty Chief Editor, the Associate Editor and the remaining reviewer. The original article has been updated.

Copyright $\odot 2019$ Frontiers Editorial Office. This is an open-access article distributed under the terms of the Creative Commons Attribution License (CC BY). The use, distribution or reproduction in other forums is permitted, provided the original author(s) and the copyright owner(s) are credited and that the original publication in this journal is cited, in accordance with accepted academic practice. No use, distribution or reproduction is permitted which does not comply with these terms. 